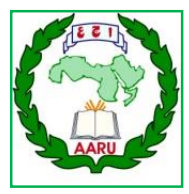

Arab Univ. J. Agric. Sci., Ain Shams Univ., Cairo, Egypt 28(1), 337-348, 2020

Website: http://ajs.journals.ekb.eg

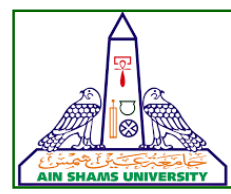

\title{
SOME ECOLOGICAL ASPECTS ON THE STRIPED MEALYBUG Ferrisia virgata (COCKERELL) INFESTING ACALYPHA SHRUBS IN QALYUBIYA GOVERNORATE, EGYPT
}

Dalia Nabil ${ }^{*}$, Amin ${ }^{2}$ A.H., Omnia M.N. Elashn ${ }^{1}$ and Youssef ${ }^{2}$ E.E.Y.

1- Plant Protection Research Institute Agriculture Research Center, Dokki, Giza, Egypt

2- Plant Protection Dept., Fac. of Agric., Ain Shams Univ., P.O. Box 68, Hadayek Shoubra 11241, Cairo, Egypt

*Corresponding author: dalianabil75@hotmail.com

Received 9 February, 2020

Accepted 1 April, 2020

\section{ABSTRACT}

Acalypha shrubs Acalypha wilkesiana Mull.(Euphorbiaceae) found to be favorable host for the striped mealybug Ferrisia virgate (Cockerell) (Pseudococcidae). This mealybug species is attacked all plant parts and caused considerable damages to this host. Some ecological aspects were carried out on $F$. virgata infesting acalypha shrubs throughout two successive years (2014-2015) and (2015-2016) in Qalyubiya Governorate.

Results obtained showed that population density was more abundant during the second year than the first one, the annual means of total population were 62.02 and 52.01 individuals/leaf), respectively. Also, results revealed that, seasonal abundance of $F$. virgata found to be active from June to January of next year. The population density was reached its maximum activity on October during both years being 123.0 and 145.2 individuals /leaf for the first and second year, respectively. The prevailing main average temperature and relative humidity were ranging between $22.8^{\circ} \mathrm{C}, 24.2^{\circ} \mathrm{C}$ and $67 \%, 64 \%$ for the $1^{\text {st }}$ and $2^{\text {nd }}$ years, respectively. These conditions seemed to be favorable conditions for insect activity. After this activity period all stages of this species were disappeared from all plant parts. This phenomenon indicate that this mealybug species was overwinter during winter and spring seasons till the next summer. From these findings it could be stated that any control measurements must be early applied during June, at the beginning of activity period of this mealybug species. Also, results clarified that $F$. virgate was passed through two annual overlapping field generations on acalypha shrubs. Duration of the first generation was ranged between 80-85 days which occurred during summer months. While the second generation was lasted 75 days and occurred during autumn. Statistical analysis revealed that separate effect of each mean, two weeks earlier of the four selected weather factors on changes in population density of $F$. virgata most factors had insignificant effects except mean minimum temperature which had positive significant effects throughout the both years ( $r$ coefficient values were 0.589 and 0.677 ). While the combined effects of the four selected factors (mean minimum, maximum temperature, average temperature and mean percentage of relative humidity), two weeks earlier, had significant effects, as a group on the change in population density especially during (2014-2015), the explained variance was $79.2 \%$ and $F$ value 14.4 .

Keywords: Ferrisia virgata; Acalypha shrubs; Seasonal fluctuations; Ecological studies; Number of generations

\section{INTRODUCTION}

During last decade the striped mealybug Ferrisia virgate (Cockerell) became the most common pseudococcid species which widely distributed in different localities of Egypt. This mealybug species was recorded for the first time in Egypt infesting acalypha shrubs and ornamental plants in Port Said Governorate (Hosny 1943). This insect is polyphagus and found to attack 203 plant genera of 77 families (Garcia et al 2016). In Egypt $F$. virgata found to attack a wide range of host plants especially ornamental plants and fruit trees. All stages of this mealybug species found to attack all plant parts, leaves, root, branches, fruits and trunk sucking a 
large amounts of plant sap then producing honey dew which considered as suitable media for growth of the black sooty mold fungi forming a black layer on leaves which delay photosynthesis and block respiration. Also, this species has the ability to transfer viruses which cause many diseases to some host plants (Franco et al 2009). Acalypha shrub Acalypha wilkesiana Mull. (Euphorbiaceae) is an important ornamental plant in Egypt and found to be a favorable host plant for this mealybug species all over the country. This mealybug species attracted the attentions of many authors in Egypt. They were published several papers on biology, ecology and natural enemies of this insect species i.e. Ammar et al (1979); Attia (1997); Balboul (2003); El-Shazly (2006); El-Batran et al (2015) and Adly et al (2016).

The present studies were conducted to investigate some ecological aspects on $F$. virgata infesting acalypha shrubs in Qalyubiya Governorate throughout two successive years. These aspects were seasonal fluctuation in population density, number and duration of annual field generations and the effect of four weather factors on the changes in insect population. These aspects could be detected the proper time for application of control measurements against this insect pest.

\section{MATERIAL AND METHODS}

These studies were carried out to investigate the seasonal fluctuation in population density and number of annual field generations of the mealybug Ferisia virgata (Cockerrel) infesting acalypha shrubs Acalypha wilkesiana Mull. in Qalyubiya Governorate throughout two successive years (20142015) and (2015-2016).

\section{Sampling and counting procedures}

Five acalypha shrubs of the same age, size, vegetation and height were chosen for sampling procedures at the Faculty of Agriculture, Ain Shams University, Shoubra El-Kheima, Qalyubiya Governorate. No chemical control measures were applied two years before sampling periods as well as during sampling procedures.

Regular samples were taken at half monthly intervals from acalypha shrubs throughout the two successive years. Each sample was consisted of 50 leaves taken randomly (10 leaves/ shrub). These samples were kept in polyethylene bags and transferred to the laboratory for inspection using a stereomicroscope. The numbers of alive individual of different developmental stages were sorted and counted. These different developmental stages were $1^{\text {st }}, 2^{\text {nd }}, 3^{\text {rd }}$ nymphal instars and adult females.

\section{1- Seasonal fluctuations of insect population}

Data of half monthly counts were used to calculate some ecological parameters. Mean of total numbers of alive individuals/leaf in each sample were considered as population index for population density. Mean of total numbers of immature stage/leaf were calculated and considered as seasonal activity period of nymphal stage throughout the year. The rate of increase in the population density was calculated by dividing the total number of alive populations in any count over the total numbers of the previous one.

\section{2- Number and duration of annual field genera- tions}

Number and duration of annual field generations were estimated on acalypha shrubs in Qalyubiya locality throughout the two years. Data of the half monthly counts of mean alive total population/ leaf were used to estimate the number and duration of the annual field generations. These data were worked out according to the methods suggested by Audemard and Millaire (1975) and emended by lacob (1977). The graphical representations of these data were carried out by using computer software program (Sigmaphot, ver.11).

\section{3- Effects of certain weather factors on the changes of population density}

Four main weather factors were selected i.e.; mean minimum, maximum temperature, average temperature and mean percentage of relative humidity. These data were obtained from the nearest Meteorological Station in Qalyubiya belonging to the Central Laboratory for Agricultural Climate (C.L.A.C.), Ministry of Agriculture, Giza, Egypt.

The half monthly means of these main weather factors were calculated. These means were used to investigate the effects of these selected weather factors, two weeks earlier, on the change of population density of $F$. virgata. Half monthly mean numbers of $F$. virgata total population were used as dependent factor $(\mathrm{Y})$, while means of half monthly records of main weather factors, two weeks earlier, were used as independent factors, mean minimum temperature $\left(\mathrm{X}_{1}\right)$; mean maximum temperature $\left(\mathrm{X}_{2}\right)$; average temperature $\left(X_{3}\right)$ and mean percentage of relative humidity $\left(\mathrm{X}_{4}\right)$. 
Statistical analysis procedures were conducted in two steps, the first one to investigate the effect of each factor separately by applying simple correlation formula and regression coefficient was used as a measure of significance. The second step by applying C-multiplier formula (Fisher, 1950) to investigate the combined effects of the four tested factors as a group on the changes of the population density expressed a percentage of explained variance (E.V.\%) and the variance ratio ( $F$ value) was used as measure of significance. All calculations were carried out using the computer program (SPSS ver.20).

\section{RESULTS AND DISCUSSION}

1- Seasonal fluctuations in population of different developmental stages of $F$. virgata infesting Acalypha Shrubs in Qalyubiya Governorate during two successive years.

Data of the half monthly counts of different developmental stages of $F$. virgata on acalypha shrubs throughout two successive years (2014-2015 and 2015-2016) with corresponding means of main weather factors are given in Tables (1 \&2).

\subsection{Seasonal fluctuations of population}

Mean of total numbers per leaf of half monthly counts were represented population index for seasonal activity. Results obtained showed that total population was more abundant during second year (2015-2016) than the first one (2014-2015), the annual means of total population were 62.01 and 52.01 individuals/leaf, respectively.

During the first year total insect population was started its activity on $1^{\text {st }}$ June, 2014 with few numbers and increased gradually throughout the successive counts and recorded the highest peak of seasonal abundance on mid October 2014, (123.00 individuals/ leaf). Then total population was decreased gradually throughout the successive counts till $1^{\text {st }}$ January 2015. Afterwards the insect population was totally disappeared till mid-June of next year. This phenomenon indicate that the insect overwinter during winter and spring seasons. Regarding rate of increase of half monthly counts as calculated by dividing the mean of total population for any count by the preceding one showed that the highest value was 8.55 which occurred on $1^{\text {st }}$ July 2014 which followed by another smaller one in midAugust being 3.80 .
During the second year the insect population nearly followed the same trend but began to be active on $1^{\text {st }}$ June (15 days later than the first year). Total insect population began with few numbers and increased gradually throughout successive counts and recorded the highest peak of seasonal abundance on $1^{\text {st }}$ October, 2015 (145.20 individuals/leaf). Then insect population was decreased gradually throughout successive counts till $1^{\text {st }}$ January 2016. Afterwards, the insect population was totally disappeared till next June. The rate of increase was recorded two maximum rates on mid-July and mid-August 2015, being 4.57 and 3.29, respectively. From these results it could be stated that seasonal abundance of $F$. virgata found to be active from June to January and reached its maximum activity on October on both years. The prevailing averages of temperature and relative humidity were ranged between $22.8^{\circ}$ to $24.2^{\circ} \mathrm{C}$ and $67 \%$ to $64 \%$ for the $1^{\text {st }}$ and $2^{\text {nd }}$ years, respectively. These conditions seemed to be favorable conditions for insect activity.

\subsection{Seasonal fluctuations of different devel- opmental stages}

\section{-Adult stage}

Mean of adult females per leaf of half monthly counts were represented adult stage because this mealybug species is reproduced parthenogenesis under local conditions. During the first season, adult female began to be active since $1^{\text {st }}$ June 2014 and increased gradually in the successive counts and recorded the highest peak as seasonal abundance on mid-October (32.4 females/ leaf). Afterwards, population of adult female decreased gradually in successive count, then disappeared from mid-January till $1^{\text {st }}$ June of the next year.

During the second year, population of adult females followed the same trend, but started to be active on $1^{\text {st }}$ June 2015 (two weeks later than the first year). Also, female population began to be active on mid-June with few numbers and increased gradually in the successive counts and recorded the highest peak on $1^{\text {st }}$ October 2015 (32.2 females/ leaf). Afterwards, population of adult females was decreased gradually in the successive counts then disappeared from mid-January 2016 till the activity period of the next year. 
Table 1. Seasonal fluctuations in population of Ferrisia virgata different stages infesting acalypha shrubs with corresponding means of main weather factors in Qalyubiya Governorate during 2014-2015

\begin{tabular}{|c|c|c|c|c|c|c|c|c|c|c|c|}
\hline \multirow[b]{2}{*}{ Dates } & \multicolumn{6}{|c|}{ Mean no. of $\boldsymbol{F}$. virgata different stages/ leaf } & \multirow{2}{*}{$\begin{array}{c}\text { Rate of } \\
\text { increase }\end{array}$} & \multicolumn{3}{|c|}{ Temp. $\left({ }^{\circ} \mathbf{C}\right)$} & \multirow[b]{2}{*}{ R.H.\% } \\
\hline & $\begin{array}{c}1^{\text {st }} \\
\text { instar }\end{array}$ & $2^{\text {nd }}$ & $\begin{array}{c}3^{\text {rd }} \\
\text { instar }\end{array}$ & $\begin{array}{c}\text { Total of } \\
\text { immature stage }\end{array}$ & Adults & Total pop. & & Max. & Min. & Avg. & \\
\hline $15 / 5 / 2014$ & - & - & - & - & - & - & - & 31.0 & 17.7 & 24.3 & 61 \\
\hline 01/06/2014 & 0.52 & 0.56 & 0.48 & 1.56 & 0.24 & 1.80 & - & 31.9 & 19.3 & 25.6 & 61 \\
\hline $15 / 06 / 2014$ & 0.20 & 0.34 & 0.26 & 0.80 & 0.30 & 1.10 & 0.61 & 33.1 & 20.1 & 26.6 & 63 \\
\hline 01/07/2014 & 2.26 & 2.20 & 2.36 & 6.82 & 2.58 & 9.40 & 8.55 & 33.4 & 21.3 & 27.4 & 64 \\
\hline $15 / 07 / 2014$ & 2.88 & 2.60 & 2.50 & 7.98 & 3.26 & 11.24 & 1.20 & 32.5 & 21.9 & 27.2 & 65 \\
\hline 01/08/2014 & 11.02 & 4.86 & 2.64 & 18.52 & 3.14 & 21.66 & 1.93 & 32.9 & 22.8 & 27.9 & 66 \\
\hline $15 / 08 / 2014$ & 33.80 & 18.30 & 23.58 & 75.68 & 6.60 & 82.28 & 3.80 & 35.4 & 20.3 & 27.8 & 73 \\
\hline 01/09/2014 & 34.64 & 24.58 & 35.60 & 94.82 & 13.94 & 108.76 & 1.32 & 30.9 & 21.2 & 26.1 & 66 \\
\hline $15 / 09 / 2014$ & 33.54 & 44.22 & 17.90 & 95.66 & 18.36 & 114.02 & 1.05 & 30.5 & 20.9 & 25.7 & 65 \\
\hline 01/10/2014 & 46.40 & 31.26 & 13.46 & 91.12 & 31.80 & 122.92 & 1.08 & 27.5 & 18.0 & 22.8 & 67 \\
\hline $15 / 10 / 2014$ & 55.30 & 24.30 & 10.98 & 90.58 & 32.42 & 123.00 & 1.00 & 26.6 & 16.9 & 21.8 & 65 \\
\hline $01 / 11 / 2014$ & 27.06 & 31.26 & 7.10 & 65.42 & 19.56 & 84.98 & 0.69 & 24.8 & 14.9 & 19.8 & 66 \\
\hline $15 / 11 / 2014$ & 19.46 & 16.30 & 7.34 & 43.10 & 8.58 & 51.68 & 0.61 & 21.6 & 11.9 & 16.8 & 79 \\
\hline $01 / 12 / 2014$ & 14.10 & 10.64 & 4.18 & 28.92 & 2.86 & 31.78 & 0.61 & 21.9 & 12.8 & 17.4 & 65 \\
\hline $15 / 12 / 2014$ & 7.90 & 2.64 & 1.34 & 11.88 & 1.58 & 13.46 & 0.42 & 19.5 & 8.6 & 14.0 & 67 \\
\hline 01/01/2015 & 1.22 & 0.32 & 0.20 & 1.74 & 0.40 & 2.14 & 0.16 & 18.9 & 8.1 & 13.5 & 72 \\
\hline $15 / 01 / 2015$ & 0 & 0 & 0 & 0 & 0 & 0 & 0 & 23.2 & 9.6 & 16.4 & 66 \\
\hline 01/02/2015 & 0 & 0 & 0 & 0 & 0 & 0 & 0 & 20.6 & 8.3 & 14.4 & 58 \\
\hline $15 / 02 / 2015$ & 0 & 0 & 0 & 0 & 0 & 0 & 0 & 19.6 & 8.1 & 13.9 & 64 \\
\hline 01/03/2015 & 0 & 0 & 0 & 0 & 0 & 0 & 0 & 23.2 & 9.4 & 16.3 & 81 \\
\hline $15 / 03 / 2015$ & 0 & 0 & 0 & 0 & 0 & 0 & 0 & 23.6 & 10.4 & 17.0 & 59 \\
\hline 01/04/2015 & 0 & 0 & 0 & 0 & 0 & 0 & 0 & 23.7 & 11.6 & 17.6 & 64 \\
\hline $15 / 04 / 2015$ & 0 & 0 & 0 & 0 & 0 & 0 & 0 & 28.9 & 12.6 & 20.7 & 57 \\
\hline 01/05/2015 & 0 & 0 & 0 & 0 & 0 & 0 & 0 & 31.5 & 14.0 & 22.8 & 79 \\
\hline $15 / 05 / 2015$ & 0 & 0 & 0 & 0 & 0 & 0 & 0 & 31.5 & 15.4 & 23.4 & 68 \\
\hline Total & & & & & & 780.22 & & & & & \\
\hline Mean & & & & & & 52.01 & & & & & \\
\hline
\end{tabular}


Table 2. Seasonal fluctuations in population of Ferrisia virgata different stages infesting acalypha shrubs with corresponding means of main weather factors in Qalyubiya Governorate during 2015-2016

\begin{tabular}{|c|c|c|c|c|c|c|c|c|c|c|c|}
\hline \multirow[b]{2}{*}{ Dates } & \multicolumn{6}{|c|}{ Mean no. of $F$. virgata different stages/ leaf } & \multirow[b]{2}{*}{$\begin{array}{l}\text { Rate of } \\
\text { increase }\end{array}$} & \multicolumn{3}{|c|}{ Temp. $\left({ }^{\circ} \mathrm{C}\right)$} & \multirow[b]{2}{*}{ R.H.\% } \\
\hline & $\begin{array}{c}1^{\text {st }} \\
\text { instar }\end{array}$ & $\begin{array}{c}2^{\text {nd }} \\
\text { instar }\end{array}$ & $\begin{array}{c}3^{\text {rd }} \\
\text { instar }\end{array}$ & $\begin{array}{c}\text { Total of } \\
\text { immature } \\
\text { stage }\end{array}$ & Adults & $\begin{array}{l}\text { Total } \\
\text { pop. }\end{array}$ & & Max. & Min. & Avg. & \\
\hline $15 / 05 / 2015$ & 0 & 0 & 0 & 0 & 0 & 0 & - & 31.5 & 15.4 & 23.4 & 68 \\
\hline 01/06/2015 & 0.38 & 0.54 & 0.26 & 1.18 & 0.34 & 1.52 & - & 30.6 & 18.2 & 24.4 & 63 \\
\hline $15 / 06 / 2015$ & 0.58 & 0.68 & 0.58 & 1.84 & 0.58 & 2.42 & 0.00 & 33.5 & 15.5 & 24.5 & 78 \\
\hline 01/07/2015 & 3.46 & 2.86 & 3.18 & 9.50 & 1.56 & 11.06 & 1.59 & 34.0 & 14.0 & 24.0 & 78 \\
\hline $15 / 07 / 2015$ & 11.58 & 6.80 & 3.96 & 22.34 & 5.56 & 27.90 & 4.57 & 35.5 & 16.5 & 26.0 & 75 \\
\hline 01/08/2015 & 39.04 & 24.50 & 18.46 & 82.00 & 9.90 & 91.90 & 2.52 & 35.2 & 21.1 & 28.2 & 59 \\
\hline $15 / 08 / 2015$ & 35.86 & 33.50 & 27.90 & 97.26 & 15.86 & 113.12 & 3.29 & 36.3 & 18.3 & 27.3 & 77 \\
\hline 01/09/2015 & 37.82 & 41.58 & 31.74 & 111.14 & 19.70 & 130.84 & 1.23 & 30.2 & 17.3 & 23.8 & 66 \\
\hline $15 / 09 / 2015$ & 42.58 & 43.26 & 19.86 & 105.70 & 29.86 & 135.56 & 1.16 & 30.0 & 18.4 & 24.2 & 64 \\
\hline 01/10/2015 & 50.60 & 37.90 & 24.50 & 113.00 & 32.16 & 145.16 & 1.04 & 30.0 & 19.2 & 24.6 & 70 \\
\hline $15 / 10 / 2015$ & 37.90 & 19.78 & 17.26 & 74.94 & 24.46 & 99.40 & 1.07 & 28.0 & 18.7 & 23.4 & 65 \\
\hline $01 / 11 / 2015$ & 27.90 & 24.22 & 8.26 & 60.38 & 19.34 & 79.72 & 0.68 & 24.3 & 15.9 & 20.1 & 70 \\
\hline $15 / 11 / 2015$ & 17.46 & 17.90 & 4.12 & 39.48 & 12.46 & 51.94 & 0.80 & 23.7 & 12.8 & 18.3 & 76 \\
\hline $01 / 12 / 2015$ & 13.06 & 7.38 & 2.06 & 22.50 & 4.22 & 26.72 & 0.65 & 18.0 & 9.6 & 13.8 & 73 \\
\hline $15 / 12 / 2015$ & 5.22 & 2.52 & 1.26 & 9.00 & 1.46 & 10.46 & 0.51 & 17.8 & 8.5 & 13.2 & 73 \\
\hline $01 / 01 / 2016$ & 1.12 & 0.74 & 0.46 & 2.32 & 0.24 & 2.56 & 0.39 & 18.7 & 8.7 & 13.7 & 65 \\
\hline $15 / 01 / 2016$ & 0 & 0 & 0 & 0 & 0 & 0 & 0.24 & 19.2 & 8.5 & 13.8 & 64 \\
\hline 01/02/2016 & 0 & 0 & 0 & 0 & 0 & 0 & 0 & 21.2 & 7.0 & 14.1 & 71 \\
\hline $15 / 02 / 2016$ & 0 & 0 & 0 & 0 & 0 & 0 & 0 & 25.2 & 10.0 & 17.6 & 78 \\
\hline 01/03/2016 & 0 & 0 & 0 & 0 & 0 & 0 & 0 & 25.8 & 11.6 & 18.7 & 67 \\
\hline $15 / 03 / 2016$ & 0 & 0 & 0 & 0 & 0 & 0 & 0 & 22.8 & 10.0 & 16.4 & 63 \\
\hline $01 / 04 / 2016$ & 0 & 0 & 0 & 0 & 0 & 0 & 0 & 27.6 & 14.3 & 20.9 & 62 \\
\hline $15 / 04 / 2016$ & 0 & 0 & 0 & 0 & 0 & 0 & 0 & 31.4 & 15.3 & 23.4 & 57 \\
\hline $01 / 05 / 2016$ & 0 & 0 & 0 & 0 & 0 & 0 & 0 & 32.3 & 15.6 & 23.9 & 63 \\
\hline $15 / 05 / 2016$ & 0 & 0 & 0 & 0 & 0 & 0 & 0 & 33.0 & 17.8 & 25.4 & 60 \\
\hline Total & & & & & & 930.28 & & & & & \\
\hline Mean & & & & & & 62.02 & & & & & \\
\hline
\end{tabular}




\section{-Immature stage}

Nymphal stage of $F$. virgata has three nymphal instars. Mean total numbers of immature stage per leaf were represented seasonal activity of this mealybug species throughout the year.

During the first year (2014-2015) population of immature stage was began to be active from $1^{\text {st }}$ June and continued till $1^{\text {st }}$ January 2015 . Nymphal population was started with few numbers in $1^{\text {st }}$ June and increased gradually in the successive counts and recorded the highest peak of seasonal abundance on mid-September 2014 (95.7 nymphs/leaf). Afterwards, the nymphal population was decreased gradually in the successive counts then disappeared at the end of season of activity on $1^{\text {st }}$ January 2015.

During the second year (2015-2016) population of immature stage was followed the same trend of the first year. Immature stage was started to be active on $1^{\text {st }}$ June 2015 (two weeks later than first year) and continued till $1^{\text {st }}$ January 2016 . Total population of immature stage started with few numbers and increased gradually in the successive counts and recorded the highest peak of seasonal abundance on $1^{\text {st }}$ October 2015 (113.0 nymphs/leaf). Afterwards, nymph's population decreased gradually till the end of seasonal activity on $1^{\text {st }}$ January, 2016.

\section{Nymphal instars}

Regarding the activity of the three nymphal instars throughout the activity period of $F$. virgata on acalypha shrubs results showed that the three nymphal instars were recorded in all counts during activity period from June 2014 to January 2015 and disappeared during overwinter period (January- mid May). Population of the three nymphal instars were started with few numbers at the beginning of the activity period and increased gradually during the successive counts and each instar was recorded one peak at seasonal abundance throughout activity period. These peaks were occurred on mid-October for first instar; on mid -September for second instar and on $1^{\text {st }}$ September for the third instar. Mean population densities for these peaks were 55.30, 44.22 and 35.60 nymphs / leaf for $1^{\text {st }}, 2^{\text {nd }}$ and $3^{\text {rd }}$ instars, respectively.

During the second year (2015-2016) population of the three nymphal instars was followed the same trend and began to be active from $1^{\text {st }}$ June 2015 to $1^{\text {st }}$ January, 2016 (two weeks later). Also, the population of the three nymphal instars were began with few numbers and increased gradually throughout successive counts and recorded one peak of seasonal abundance for each instar. These peaks were occurred in $1^{\text {st }}$ October; mid-September and $1^{\text {st }}$ September 2015. Means of nymphal population densities for the three instars were 50.60, 43.26 and 31.74 nymphs/leaf, respectively.

From the above mentioned results it could be stated that the different developmental stages of $F$. virgata had one activity period of annually, extended from June to January. While the period from midJanuary to next June the nymphal stages were disappeared from leaves of all samples and may moved to other parts of this host to overwinter.

Mean of the half-monthly counts of total immature stage as well as the three nymphal instars recorded one peak of seasonal abundance during the period from $1^{\text {st }}$ September to mid-October 2014 for first year while during the second year from $1^{\text {st }}$ September to $1^{\text {st }}$ October 2015. Mean of main weather factors prevailing during these periods were ranged between 27.8 to $22.8^{\circ} \mathrm{C}$ and $73 \%$ to $67 \%$ R.H.\% for first year and 27.3 to $24.6^{\circ} \mathrm{C}$ and $77 \%$ to $70 \%$ R.H. for second year. Therefore, this period seemed to be the favorable conditions for activity of this mealybug species.

2- Number and duration of annual field generations of $F$. virgata on acalypha shrubs in Qalyubiya Governorate during two successive years

Data of the half monthly counts represented by mean numbers of total population per leaf of acalypha were used to estimate number and duration of annual field generations throughout the two successive seasons (2014-2015) and (2015 - 2016) in Qalyubiya Governorate. The formula proposed by Audemard and Millaire (1975) and emended by lacob (1977) were applied for the data of each year. Results in Table (3) and graphically illustrated in Figs. (1\&2) showed that, during the first year (2014 -2015) the first generation was extended from $1^{\text {st }}$ August to mid October 2014 and lasted 85 days where the highest total population was occurred on mid October 2014 with 123 individuals / leaf. The second generation was elapsed from mid-October to $1^{\text {st }}$ January 2015 and lasted 75 days. Afterwards the population of $F$. virgata completely disappeared till the end of the year.

During the second year (2015-2016) first generation was started from mid-August till mid October 2015 and lasted 80 days. Also, the highest total population was recorded on mid-October with 145.16 individuals/ leaf. The second generation was started from $1^{\text {st }}$ November till mid-January 2016 and lasted 75 days. 
Some Ecological Aspects on the Striped Mealybug Ferrisia virgata (Cockerell) Infesting Acalypha Shrubs in Qalyubiya Governorate, Egypt

Table 3. Durations of $F$. virgata generations in Qalyubiya Governorate on acalypha shrubs during 2014-2015 and 2015-2016

\begin{tabular}{|c|c|c|}
\hline Generations & Generation period & $\begin{array}{l}\text { Generation } \\
\text { in days }\end{array}$ \\
\hline \multicolumn{3}{|l|}{ 2014-2015 } \\
\hline $1^{\text {st }}$ generation & From $1^{\text {st }}$ August till $15^{\text {th }}$ October & 85 days \\
\hline $2^{\text {nd }}$ generation & From $15^{\text {th }}$ October till $1^{\text {st }}$ January & 75 days \\
\hline \multicolumn{3}{|l|}{ 2015-2016 } \\
\hline $1^{\text {st }}$ generation & From $15^{\text {th }}$ August till $15^{\text {th }}$ November & 80 days \\
\hline $2^{\text {nd }}$ generation & From $1^{\text {st }}$ November till $15^{\text {th }}$ January & 75 days \\
\hline
\end{tabular}

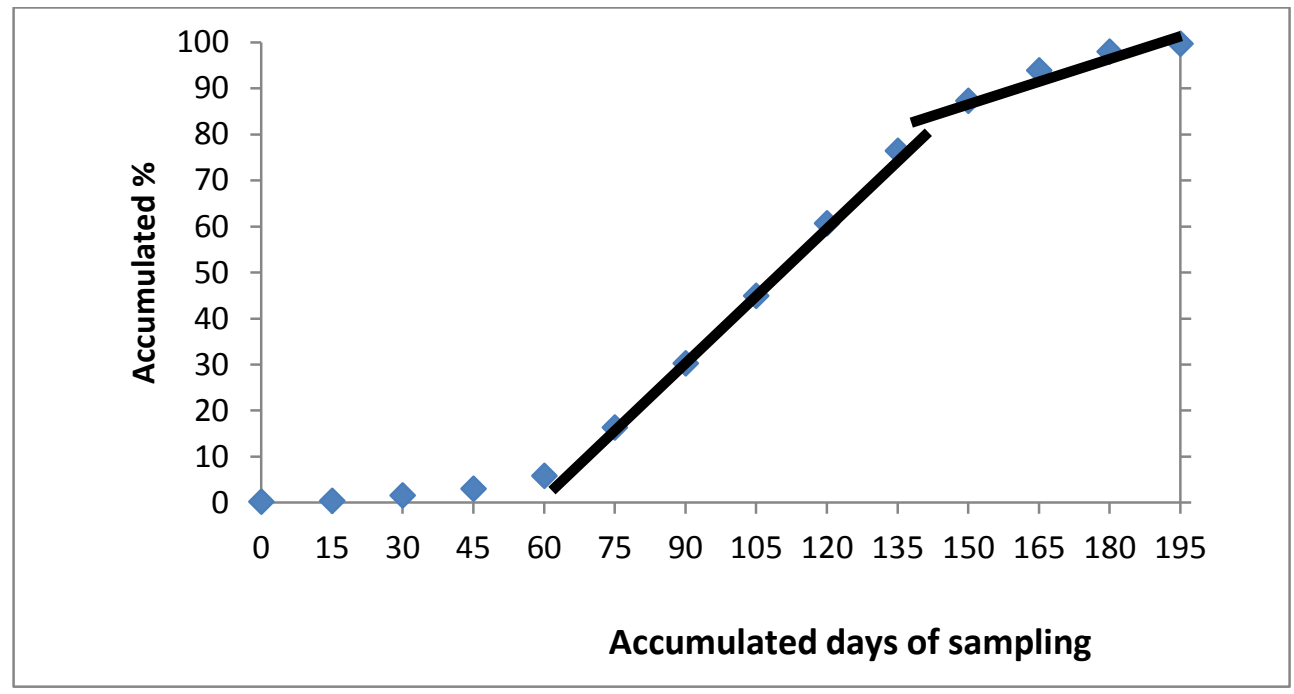

Fig. 1. Number of F. virgata generations on acalypha shrubs at Qalyubiya Governorate 2014 -2015. 


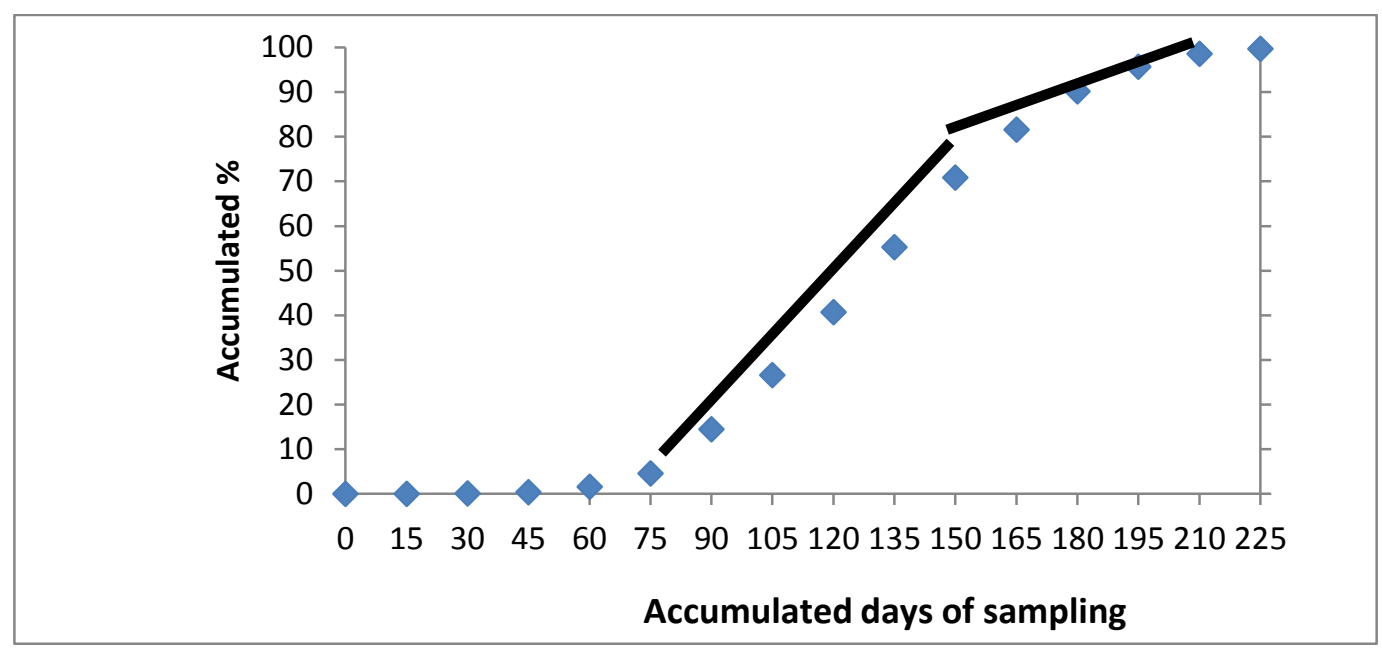

Fig. 2. Number of F. virgata generations on acalypha shrubs at Qalyobiya Governorate 2015 -2016.

Afterwards, the population of $F$. virgata was disappeared on acalypha shrubs until the end of the year.

From the aforementioned results it could be stated that $F$. virgata passed through two overlapping generations on acalypha shrubs under field conditions of Qalyubiya Governorate. Duration of the first generation was ranged between $80-85$ days which occurred during summer months. While the second generation was lasted 75 days during autumn. Afterward the population of this mealybug species was disappeared during winter and spring till the summer of next year.

3- Effects of main weather factors on the changes in population density of $F$. virgata on acalypha shrubs in Qalyubiya Governorate during two successive years

Half monthly means of the four main weather factors two weeks earlier, were tested to clarify their simultaneous effects on the changes in population density of $F$. virgata on acalypha shrubs in Qalyubiya Governorate during two successive years (2014-2015) \& (2015-2016).

The half monthly mean numbers of total population per leaf represented the population density throughout the main activity periods (from $1^{\text {st }}$ June 2014 to $1^{\text {st }}$ January 2015) and ( $1^{\text {st }}$ June 2015 to $1^{\text {st }}$ January 2016).

Results of statistical analysis are given in Table (4) for the two years.

\section{- Effect of mean maximum temperature}

Results showed that this factor had positive insignificant effects on the changes of population density during the two years.

\section{- Effect of mean minimum temperature}

Results indicated that this factor had positive significant effects on the changes of population density. The correlation coefficient $(r)$ values were 0.589 and 0.677 for first and second years and the unit effect (b) value were 8.71 and 0.65 individuals, respectively.

\section{- Effect of average temperature}

Results showed that this factor had positive insignificant effects on the changes of population during the two years.

\section{- Effect of mean percentage of relative humidity}

Results revealed that this factor had positive insignificant effect during 2014-2015. While the same factor had negative insignificant effect during 20152016.

\section{- The combined effects of the four selected fac- tors}

Results of statistical analysis revealed that the four selected weather factors were responsible as a group for $79.2 \%$ in the changes of population density of this mealybug species during 2014-2015 year. The "F" value was 14.4 with highly significant at $1 \%$ level of probability. While during 2015-2016 the same factors showed insignificant effects. 
Table 4. Results of statistical analysis (simple correlation, partial regression and analysis of variance) on the relationship between the effects of four weather factors two weeks earlier on the changes in population of $F$. virgata infesting acalypha shrubs at Qalyubiya Governorate during 2014-2015and 2015-2016.

\begin{tabular}{|c|c|c|c|c|c|c|c|c|c|c|c|c|c|c|}
\hline \multicolumn{8}{|c|}{ 2014-2015 } & \multicolumn{7}{|c|}{ 2015-2016 } \\
\hline \multirow{2}{*}{$\begin{array}{c}\text { Tested } \\
\text { variables }\end{array}$} & \multicolumn{3}{|c|}{ Simple correlation } & \multicolumn{3}{|c|}{ Regression values } & \multirow{2}{*}{ 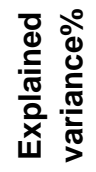 } & \multicolumn{3}{|c|}{$\begin{array}{c}\text { Simple } \\
\text { correlation }\end{array}$} & \multicolumn{3}{|c|}{$\begin{array}{c}\text { Regression } \\
\text { values }\end{array}$} & \multirow{2}{*}{ 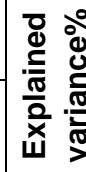 } \\
\hline & "r" & Prob. & "b" & s.e. & "t" & Prob. & & "r" & Prob. & "b" & s.e. & "t" & Prob. & \\
\hline $\begin{array}{l}\text { Max. } \\
\text { temp. }\end{array}$ & 0.352 & 0.198 & --- & 4.79 & 0.09 & 0.927 & 79.2 & 0.405 & 0.120 & $\mid---$ & 9.26 & 0.60 & 0.559 & 30.5 \\
\hline Min & 0.589 & 0.021 & 8.71 & 4.45 & 5.98 & 0.0001 & & 0.677 & 0.004 & 0.65 & 8.98 & 1.91 & 0.082 & "F" \\
\hline Aver. & & & & & & & value & & & & & & & value \\
\hline Temp. & 0.289 & 0.295 & & 4.27 & 2.81 & 0.019 & $14.4^{\star *}$ & 0.416 & 0.109 & |--- & 8.80 & 0.31 & 0.761 & 2.64 \\
\hline R.H.\% & 0.265 & 0.339 & & 1.37 & 3.88 & 0.003 & & -0.401 & 0.124 & ---- & 4.00 & 0.58 & 0.571 & \\
\hline
\end{tabular}

From these results it could be concluded that the changes in population density of $F$. virgata was mostly related to the combined effects of the four selected factors, two weeks earlier, than each factor separately special during the first year.

\section{DISCUSSION AND CONCLUSION}

Ecological studies on Ferrisia virgata (Cockerrel) were carried out on acalypha shrubs in Qalyubiya Governorate throughout two successive years 2014-2015 and 2015-2016. The obtained results revealed the following points:

-Population density of this mealybug species was more abundant during the second year than the first one. The annual averages of total population were 52.01 and 62.02 individuals / leaf on acalypha shrubs during (2014-2015) and (20152016), respectively. These results in harmony with those obtained by Nalini (2015) who stated that population density of $F$. virgata was more active during 2009 as compared with 2008 on guava trees in India. He added that this was due to increase of temperature and decrease of relative humidity.

-Seasonal activity in population density of $F$. virgata showed that this mealybug species had main period of activity throughout the two years. This period was extended from June to January of next year. Afterwards, all stages of this species were disappeared from leaves till the next season. This species was overwintered during winter and early spring at any stages probably under park or root of this host or fallen leaves and probably in soil.
These results in agreement with those obtained by Ammar et al (1979) who stated that activity period of $F$. virgata was extended from mid-June to midOctober, afterwards different developmental stages were disappeared from $1^{\text {st }}$ January to $1^{\text {st }}$ June on acalypha shrubs in Giza Governorate.

-Seasonal fluctuation in insect population density of this mealybug species was represented by population index (mean number of alive total population/leaf) of the half monthly counts during the two years. Insect population started its seasonal activity in June and increased gradually in the successive counts. The population density was recorded the highest peak of seasonal abundance on October during both of the two years on acalypha shrubs. The population indexes were 123.0 and 145.2 individuals/ leaf for the first and second year, respectively on acalypha shrubs. These results are in harmony with those obtained by Dawood (1971) who stated that $F$. virgata recorded one peak of seasonal abundance on August on dahlia plants in Egypt. Adly et al (2016) stated that population of this mealybug species recorded one peak of seasonal abundance on November on guava trees in Egypt. Also, Shanbhag and Sundaraj (2017) recorded one peak of seasonal abundance on May on sandalwood in Bangalora, India. While, El-Shazly (2006) stated that this mealybug species had two peaks of seasonal abundance on July and September on oleander plants in Giza. Also, Balboul (2003) recorded two peaks of seasonal abundance on guava trees during $1^{\text {st }}$ November and mid-October in Egypt. On the contrary, El-Batran et al (2015) recorded three 
peaks of seasonal abundance on lantana shrubs in El-Mansoura, Egypt.

- Rate of increase of insect population density was calculated by (dividing mean numbers of total population for any half monthly counts by the preceding one) this rate was recorded the highest value being 8.55 on $1^{\text {st }}$ July 2014 and 4.57 on mid-July 2015.

- Regarding the seasonal fluctuations of different developmental stages of $F$. virgata on acalypha shrubs throughout both of the two years, results showed that population of adult females during activity periods (June to January) found to be less abundance than immature stage which found to be more dominate stage in all half monthly counts during the two years.

-Adult female stage population were beginning with few numbers at the beginning of activity period. Then increased gradually throughout successive counts and recorded the highest peaks on October during the two years being 32.42 and 32.16 females/leaf on acalypha shrubs.

- Immature stage population was represented by total numbers of the three nymphal instars during the period of activity (June-January) throughout the two years on acalypha. This stage was beginning with few numbers on June and increased gradually in the successive counts, then recorded the highest peaks of seasonal abundance on mid-September on acalypha shrubs during the two years being 95.66 and 113.00 nymphs/leaf.

From these findings it could be stated that any control measurements must be applied during June at the beginning of activity period of this mealybug species.

- Number and duration of annual field generations of $F$. virgate were estimated during its activity period (June-January). Results showed that this mealybug species was passed throughout two annual overlapping generations. On acalypha shrubs in Qalyubiya Governorate the first generation was extended from August to mid-October or mid-November and duration ranged between 80 85 days; while the second generation elapsed from mid-October or November to January and lasted 75 days. This mealybug species seemed to be overwintered during winter and early spring till the next year at any developmental stages under the bark and root of their hosts on fallen leaves and soil. These results were in agreement with Attia (1997) who recorded two generations for $F$. virgata on lantana and acalypha shrubs in Egypt. Also, Balboul (2003) recorded two generations for their species in Egypt on guava trees. Wunderlich et al (2013) recorded two generations for Ferrisia gilli on grapevine in California. While, Ammar et al (1979) recorded three generations for $F$. virgata on acalypha shrubs in Giza Governorate.

- The effect of four selected main weather factors (temperature and \% relative humidity, two weeks earlier) on the changes in insect population of $F$. virgata on acalypha shrubs were investigated throughout the two successive years. Results showed that each factor separately had insignificant effects for most selected factors except mean minimum temperature, which had positive significant effects on acalypha shrubs throughout the two successive years. The coefficient values were 0.589 and 0.677 for both years, respectively.

- The combined effects of the four selected factors (maximum, minimum, average temperature and percentage of relative humidity) two weeks earlier showed highly significant effects on the change in population density of the rested insect on acalypha shrubs during 2014-2015. The explained variance was $79.20 \%$ and $F$ value being 14.4. While the same factors had insignificant effect during the second year.

These results are in agreement with those obtained by Ammar et al (1979) they stated that mean minimum temperature had a positive significant on the change in population density of $F$. virgata on acalypha shrubs in Giza Governorate. They added the combined effects of main weather factors showed highly significant effects and the explained variance was $94.7 \%$. Also, Attia (1997) stated that daily means of maximum and minimum temperature showed significant positive correlation with the changes on population density of $F$. virgata on acalypha and lantana shrubs in Egypt.

Shanbhag and Sundaraj (2017) stated that mean maximum temperature and rainfall asserted positive significant effects on the change in population density of $F$. virgata on sandalwood in Bangalora, India. While, both maximum and minimum humidity showed negative significant correlation on population density.

\section{REFERENCES}

Adly D., Abul Fadl H A.A. and Mousa S.F.M. 2016. Survey and seasonal abundance of mealybug species, their parasitoids and associated predators on guava trees in Egypt. Egypt. J. Bio. Pest Cont.; 26(3), 657-664. 
Ammar E.D., Awadallah K.T. and Rashad A. 1979. Ecological studies on Ferrisia virgata (Ckll.) on acalypha shrubs in Dokki, Giza (Homoptera:Pseudococcidae). Dtsch. Ent. Z., N.F.26, Heft (V-V), Seite 207, 207-213.

Attia A.R.A. 1997. Ecological and biological studies on mealybug parasitoids at Giza region. M.Sc. Thesis, Fac. Agric., Cairo Univ., 143 p.

Audemard H. and Millaire H.G. 1975. Le pegeage du Carpocapsa (Laspeyresia) pomonella L. avec une pheromone sexuelle synthese: premiers resultata utilisables pour 1 , estimation des populations et la conduit de la lulte. Ann. Zoll. Ecol. Anim.; 7(1), 61-80.

Balboul O.A.H. 2003. Ecological safe ways for controlling some insect pests attacking the guava trees at Giza Governorate. M.Sc. Thesis, Dept. Agric. Sci.; Institute Environ. Studies and Res.; Ain Shams Univ., 148 p.

Dawood H.Z. 1971. Survey of aphids and mealybugs infesting ornamental plants. M.Sc. Thesis, Fac. Agric., Cairo Univ.; 114 p.

El-Batran L.A., Ghanim A.A., Shanab L.M. and Ramadan M.M. 2015. Population densities of some insects infesting Lantana camara L. shrubs and their predatory insects at Mansoura District. J. Plant Prot. and Path.; Mansoura Univ.; 6(5), 813-823.

El-Shazly M.M. 2006. Observations on oleander (Nerium oleander L. Apocynaceae) ecosystem in Giza, Egypt. Proc. $4^{\text {th }}$ Inter. Conf. on Urban Pests, Entomol. Dep.; Fac. Sci., Cairo Univ., 2000, 225-233.
Fisher R.A. 1950. Statistical methods for research workers. Oliver and Boy Ltd., Edinburgh, London. $12^{\text {th }}$ ed.; $518 \mathrm{p}$.

Franco J.C., Zada A. and Mendel Z. 2009. Novel approaches for the management of mealybug pests. Biorational Control of Arthropod pests. Springer, 233-278.

Garcia M., Denno B., Miller D.R., Miller G.L. and Ben-Dov Y. 2015. ScaleNet: A literature-based model of scale insect biology and systematic. http://scalenet.info.

Hosny M. 1943. Coccidae new to Egypt with notes on some other species (Hemiptera). Bulletin de la Société Fouadler d' Entomol.; 27, 113-123.

lacob N. 1977. Un model Matimatic pentra stabitirea limitelor economic de tolerenta a atacalui molilor fructilor in lupte integrate. Anal. Nstit. Cerc. Prot. Plant; 15-179.

Nalini T. 2015. Field incidence of mealybugs and its parasitization by encyrtids in various crop ecosystems. Plant Archives; 15(2), 671-676.

Shanbhag R.R. and Sundararaj R. 2017. Population dynamics of the striped mealybug Ferrisia virgata (Cockerell) (Hemiptera: Pseudococcidae) and the scope of its biological suppression in the present scenario of cultivation of indian sandalwood. Res. Agric. and Tech .11(2), 1-6.

Wunderlich L.R., Cooper M.L. and Daone K.M. 2013. Seasonal biology of Ferrisia gilli (Hemiptera: Pseudococcidae) in California Serra Foothill Vineyards. J. Econ. Entomol.; 106(4), 17161725. 


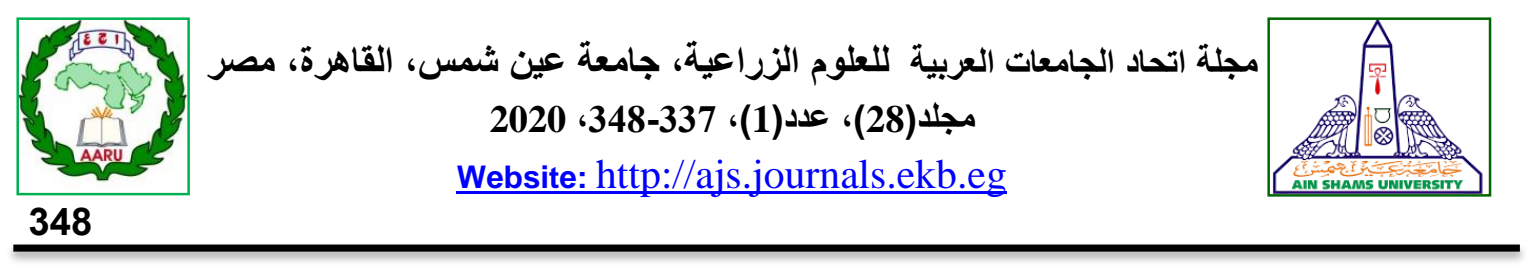

Ferrisia virgata (Cockerell) بعض المظاهر البيئية لحشرة البق الدقيقي المخط التى تصيب (Hemiptera:Coccoidea; Pseudoccidae) شجيرات الأكاليفا فى محافظة القليوبية، مصر

داليا نبيل1" - عبدالرحمن حسين أمين2 - أمنيه محمد نبيل الصحن 1 - يوسف عز الدين يوسف2 2

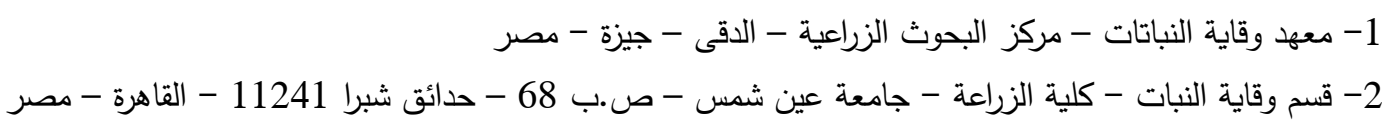

*Corresponding author: dalianabil75@hotmail.com

حتى الصيف التالي. كما أظهرت النتائج ان الحشرة لها جيلين متداخلين فى السنة على شجيرات الاكاليفا.

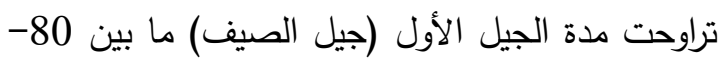

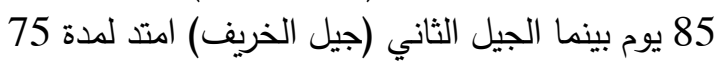

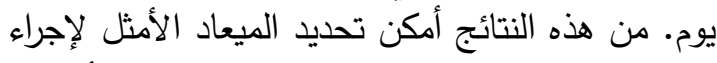

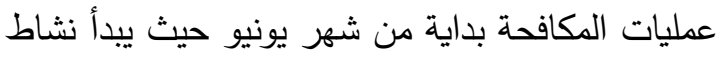

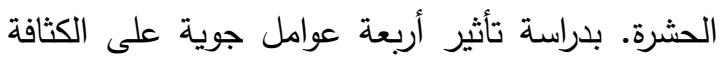

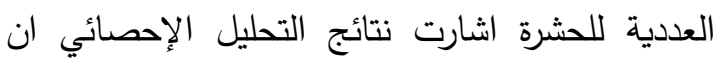

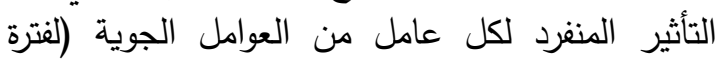

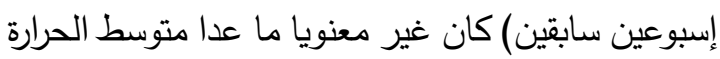

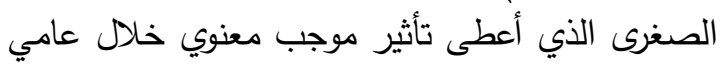

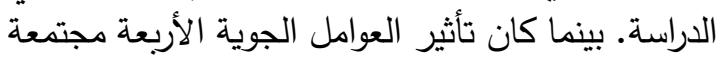

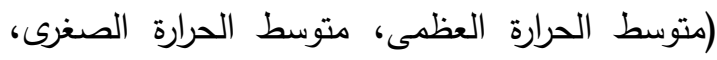
متوسط الحرارة الكلي و متوسط الرطوبة العندية النسبية ) معنوياً

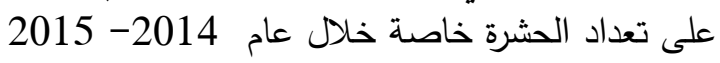

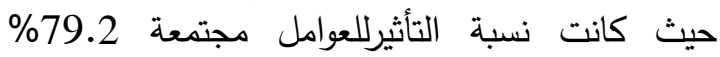
وقيمة F عالية المعنوية 14.4 وكان التأثيرغير معنوي خلال العام الثاني 2015-2016.

الكلمات المفتاحية: بق الفيرزيا، شجيرات الأكاليفا، التغيرات الموسمية، دراسات بيئية، عدد أجيال

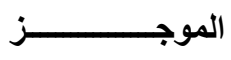

Acalypha wilkesiana تعتبر شجيرات الأكاليفا Mull. Ferrisia بالغة للنبات من العوائل المفضلة لبق الفراء النيات virgate (Cockerell) البيئية لبق الفريزيا الدقيقى على شجيرات الاكاليفا خلال

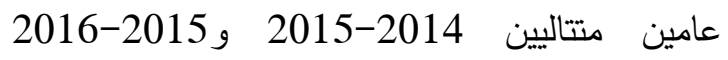
بمحافظة القليوبية. اوضحت النتائج ان كثافة تعداد

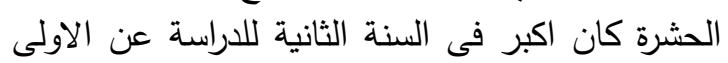
وكان متوسط التعداد الكلى السنوى 62.02 و 52.01 السينة 52.01

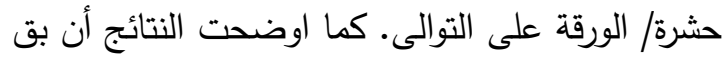

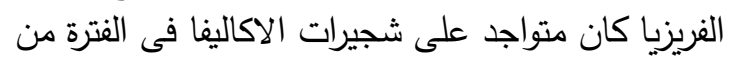

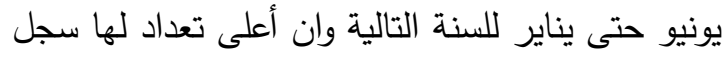
في شهر اكتوبر فى سنتى الدراسة بـ 123.0 و 145.2

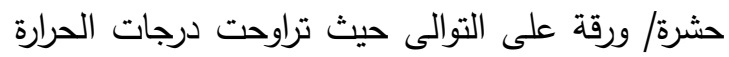

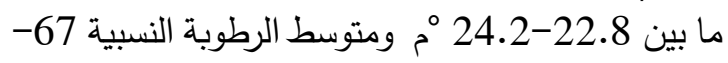

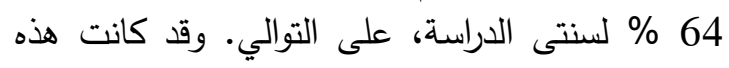

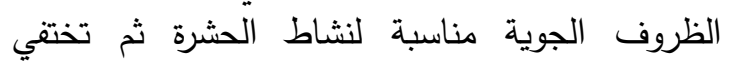

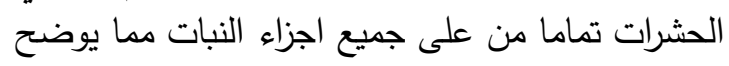
ان هذه الحشرة تدخل في بيات في موسي الشي الشتاء والربيع 